\title{
Landscape Patterns of Vegetation Canopy Regrowth Following Wildfires in the Sierra Nevada Mountains of California
}

\author{
Christopher Potter \\ NASA Ames Research Center, Moffett Field, USA \\ Email: chris.potter@nasa.gov
}

Received 2 September 2015; accepted 5 October 2015; published 8 October 2015

Copyright (C) 2015 by author and Scientific Research Publishing Inc.

This work is licensed under the Creative Commons Attribution International License (CC BY). http://creativecommons.org/licenses/by/4.0/

(c) (i) Open Access

\begin{abstract}
Rapid recovery of pioneer shrub and forest patch cover can reduce soil erosion, nutrient runoff and degradation of stream habitats, and promote small mammal and avian biodiversity following stand-replacing wildfires. Landsat imagery from the past 25+ years was analyzed to understand patterns and rates of vegetation recovery, focusing on high burn severity (HBS) patches, within wildfire areas dating from the late 1940s in the Sierra-Nevada region of California. Normalized difference vegetation index (NDVI) levels indicative of recovered woody cover within HBS areas were analyzed starting in $\mathbf{1 9 8 5}$ to quantify regrowth of patch dynamics. Analysis of landscape metrics showed that the percentage of total HBS area comprised by the largest patch of recovered woody cover was relatively small in all fires that occurred since 1995, but increased rapidly with time since fire. Patch complexity of recovered woody cover decreased notably after more than $\mathbf{5 0}$ years of regrowth, but was not readily associated with time for fires that occurred since the mid 1990s. Patch complexity of dense woody cover was consistently high in fires after 1995 and increased with the elevation of HBS areas. The aggregation level of patches with recovery of woody cover increased steadily with time since fire. The study approach using satellite remote sensing can be expanded to assess the consequences of stand-replacing wildfires in all forests of the region.
\end{abstract}

\section{Keywords}

Landsat, Forest, Wildfire, Regrowth, Disturbance, Sierra Nevada, California

\section{Introduction}

Wildfire is a major force in determining the structure of forests in the Sierra Nevada of California (Kane et al., 
2013). Understanding how these ecosystems may recover from stand-replacing fires remains a challenge, in part because wildfires typically occur at spatial scales of hundreds to thousands of hectares (van Mantgem \& Schwilk, 2009). Satellite remote sensing has been shown to be an effective method to monitor regeneration patterns of vegetation biomass and productivity following disturbance in remote mountain areas (Collins \& Woodcock, 1996; Amiro et al., 2000; Rogan \& Franklin, 2001; Rogan et al., 2003; Fischer et al., 2004; Epting \& Verbyla, 2005; Cuevas-Gonzalez et al., 2009; Casady \& Marsh, 2010, Li \& Potter, 2012; Potter, 2014).

van Wagtendonk \& Root (2003) report that the satellite normalized difference vegetation index (NDVI) can provide information necessary to distinguish vegetation cover types when analyzed over a summer growing season in the Sierra Nevada. Similar studies have found that NDVI is sensitive to early (herbaceous) post-fire recovery and subsequent woody (tree and shrub) regrowth trajectories (Potter et al., 2012; Franks et al., 2013).

Field measurements by Collins \& Roller (2013) and Goforth \& Minnich (2008) imply that sustained regrowth of mixed-conifer forests in California is uncertain in areas affected by high severity and stand-replacing wildfires. This is particularly the case for the pine component within mixed-conifer forests. Chaparral cover regrowth is commonly an early seral response to high severity fire in the Sierra Nevada. Vigorous regrowth response of such shrubs, coupled with high frequencies of hardwood forest regeneration, suggests a long-term compositional shift of mixed-conifer forests in the region.

The objective of this study was to better understand rates and landscape patterns of vegetation canopy recovery of all woody cover types (shrubs and trees) following stand-replacing fire events in the Sierra Nevada region. Regeneration of woody cover productivity is important to preserve wildlife habitats, enhance soil conservation, and protect stream water quality after HBS fire events (NPS, 2009; Fontaine \& Kennedy, 2012; Aha et al., 2014; Roberts et al., 2015). NDVI levels indicative of recovered dense vegetation cover within HBS areas from wildfires since as early as the 1940s were analyzed as landscape patches. Changes over time in patch area, dominance, complexity, and aggregation were quantified in a study approach that could be used to monitor the vegetation recovery rates of HBS areas in all forested zones of the Sierra Nevada region. This is the first study of its kind to rigorously quantify post-fire vegetation recovery in terms of well-known patch index dynamics in the Sierra Nevada region, and as such, establishes an important baseline data set for successional vegetation processes at the landscape level.

\section{Study Region}

The Sierra-Nevada region covers over $63,000 \mathrm{~km}^{2}$ along a north-south axis in California (Figure 1). Rundel et al. (1977) defined elevation zones in the Sierra-Nevada roughly as: montane $(1500-2500 \mathrm{~m})$, subalpine $(2500$ $3000 \mathrm{~m}$ ), and alpine (above $3000 \mathrm{~m}$ ). Annual precipitation in the central Sierra ranges from $80 \mathrm{~cm}$ at lower elevations to more than $170 \mathrm{~cm}$ at higher elevations, with most precipitation falling during the winter as snow (Lutz et al., 2009). Peak annual snow water equivalents (SWE) levels range from $50 \mathrm{~cm}$ to $160 \mathrm{~cm}$, depending on elevation and topography (Trujillo et al., 2012).

Major tree species in the montane zone include California black oak (Quercus kelloggii), ponderosa pine (Pinus ponderosa), Douglas-fir (Pseudotsuga menziesii), and red fir (Abies magnifica) (Rundel et al., 1977; van Wagtendonk \& Lutz, 2007). Common tree species in the subalpine zone include whitebark pine (P. albicaulis), lodgepole pine ( $P$. contorta subs. murrayana), mountain hemlock (Tsuga mertensiana), western white pine ( $P$. monticola), Sierra juniper (Juniperus occidentalis var. australis), Jeffrey pine (P. jeffreyi) and white fir (Abies concolor).

Before human settlements in the mid-1800s, conifer forests throughout the study region experienced wildfires mainly of low and moderate severity. Montane pine and mixed-conifer forests historically experienced mean fire return intervals of 11 to 16 years (Van de Water \& Safford, 2011; Miller \& Safford, 2012). In higher elevation subalpine forests of the Sierra Nevada, the typical pre-settlement fire return intervals were between $35-100$ years (Safford et al., 2011).

Several of the largest Sierra Nevada wildfires within the period 1948 to 2012 (Figure 1) were selected for study from the database compiled by the California Department of Forestry, Fire and Resource Assessment Program (FRAP), with contributions from the USDA Forest Service, the Bureau of Land Management, and the National Park Service (data available at http://frap.cdf.ca.gov/). According to the National Monitoring Trends in Burn Severity database (MTBS; Eidenshenk et al., 2007) and other historical records, these wildfire areas each had greater than 1500 ha of high burn severity (HBS) patches (Table 1). It should be acknowledged that these 


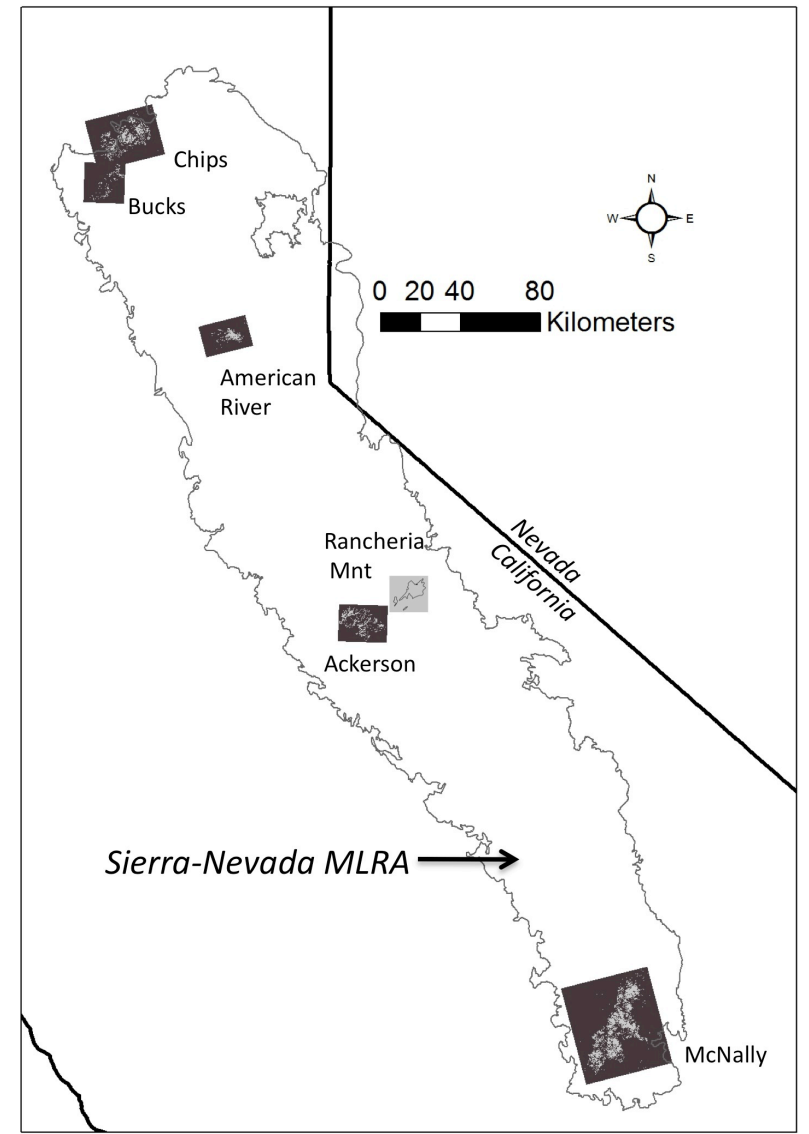

Figure 1. Map of the Sierra-Nevada region (Major Land Resource Area-MLRA; USDA, 2006) showing the locations of the wildfires listed in Table 1. Gray shaded areas are the HBS class $30-\mathrm{m}$ pixels within the wildfire zones.

Table 1. High burn severity (HBS) in fires areas selected for analysis of forest regrowth in the Sierra-Nevada.

\begin{tabular}{|c|c|c|c|c|}
\hline Fire Name & Year & HBS (ha) & $\begin{array}{c}\text { HBS (ha) with } \\
\text { NDVI }>0.5 \text { in } 2013\end{array}$ & $\begin{array}{l}\text { Percent HBS with } \\
\text { NDVI }>0.5 \text { in } 2013\end{array}$ \\
\hline Rancheria Mountain & 1948 & unknown & $944^{\mathrm{a}}$ & Unknown \\
\hline Ackerson & 1996 & 5271 & 3635 & 69 \\
\hline Bucks & 1999 & 1755 & 1592 & 91 \\
\hline McNally & 2002 & 26,609 & 5397 & 20 \\
\hline American River & 2008 & 2899 & 1014 & 35 \\
\hline Chips & 2012 & 9642 & 112 & 1 \\
\hline
\end{tabular}

${ }^{\mathrm{a}}$ Estimated based on all woody cover (shrub and forest) area not burned again since 1949.

fires occurred in areas managed by different agencies (U. S. Forest Service versus Park Service) that could have resulted in different post-fire management actions (e.g., timber salvage, herbicidal application before replanting, etc.).

For a reference forested area in the unmanaged landscape of Yosemite National Park that has been regrowing after stand-replacing wildfire for more than 50 years, the Rancheria Mountain fire in the Toulumne River drainage began on September 9, 1948. Before it was brought under control twelve days later, wildfire had burned more than 4791 ha of timberland (Board of Review Report, 1948; NPS, 1949). Judging from these historical reports, HBS area covered a large fraction of the Rancheria Mountain fire. 


\section{Methods}

\subsection{Satellite Image Processing}

Near cloud-free imagery from the Landsat-8 sensor was selected from the US Geological Survey Earth Explorer data portal (http://earthexplorer.usgs.gov/). Landsat image data from path/rows 44/33, 44/32, and 41/35 was acquired in July-August 2013, around the peak of the summer growing season (van Wagtendonk \& Root, 2003). All images used in this study were geometrically registered (UTM Zone 10) using terrain correction algorithms (Level 1T) applied by the U. S. Geological Survey EROS Data Center, and then converted to at-sensor reflectance following the algorithms from Chander et al. (2009). No further corrections for atmospheric scattering were applied, since the reflectance indices used in this study employed NIR and SWIR wavelengths that are minimally affected by atmospheric scattering (Avery \& Berlin, 1992), especially during the summer months for the Sierra Nevada study area (Miller et al., 2009).

Landsat NDVI has been commonly used in disturbance ecology to monitor such fire impacts and recovery trajectories (Lentile et al. 2006). Advantages of NDVI for the purpose of post-fire vegetation monitoring have been cited in its mathematical simplicity and ease of comparability across numerous multi-spectral remote sensing platforms.

NDVI exploits differential reflectance between the red and near-infrared (NIR) portions of the spectrum by the equation:

$$
\mathrm{NDVI}=(\mathrm{NIR}-\mathrm{Red}) /(\mathrm{NIR}+\mathrm{Red})
$$

where NIR is the reflectance of wavelengths from 0.76 to $0.9 \mu \mathrm{m}$ and Red is the reflectance from 0.63 to 0.69 $\mu \mathrm{m}$.). Low values of NDVI (near 0) indicate barren land cover whereas high values of NDVI (near 1.0) indicate dense canopy vegetation cover. van Wagtendonk \& Root (2003) showed that July-August NDVI values greater than 0.5 corresponded to dense canopy cover in conifer forest and shrubland (chaparral) types of Yosemite National Park in the central Sierra Nevada.

Burn severity within wildfire boundaries that occurred after 1995 was mapped at 30m spatial resolution by the MTBS (Eidenshenk et al., 2007) using the normalized burn ratio (NBR, Miller \& Yool, 2002; Key \& Benson, 2006). The NBR is derived from the NIR and SWIR bands of the Landsat sensors.

$$
\mathrm{NBR}=(\mathrm{NIR}-\mathrm{SWIR}) /(\mathrm{NIR}+\mathrm{SWIR})
$$

NBR (scaled by 1000 to an integer format) is influenced by land surface conditions, such as canopy density and soil surface charring. The relative difference NBR was computed as a comparison of pre- and post-fire surface conditions for the wildfires listed in Table 1.

$$
[(\text { NBRpre-fire - NBRpost-fire) }] / \sqrt{\text { ABS (NBRpre-fire) }}
$$

The absolute value (ABS) of the pre-fire NBR in the denominator allowed computation of the square-root without changing the sign of the dNBR (Miller et al., 2009). Positive RdNBR values would represent a decrease in vegetation cover and a higher burn severity, while negative values would represent an increase in vegetation cover.

Following protocols from the composite burn index (CBI; Key \& Benson, 2006), burn severity classes have been defined for conifer forest types of California (van Wagtendonk \& Lutz, 2007; Miller et al., 2009) within the following RdNBR ranges: Unburned < 42, Low $42-219$, Moderate $220-565$, and High $>565$. Within the CBI protocol, the low severity class was generally associated with little change in vegetation cover, whereas the HBS class was generally associated with complete mortality and removal of all live woody vegetation, i.e. stand replacing fire.

\subsection{Landscape Patch Analysis}

Post-wildfire landscapes are typically composed of a complex mosaic of burn severity patch classes. Regenerating vegetation with dense canopy cover (i.e., NDVI values > 0.5; after van Wagtendonk \& Root, 2003) was analyzed within the HBS class of each of the wildfires selected between 1948 and 2012 using the FRAGSTATS program (McGarigal et al., 2002). Class indices from FRAGSTATS quantify the densities and spatial configuration of patches (e.g., high NDVI), and therefore provide different metrics to quantify the shapes and aggregation levels of this patch type across the HBS landscape. 
The simplest index of landscape pattern is patch size. Patch size distribution can be summarized at the HBS class level by a variety of metrics (e.g., mean, median, max and variance). The area-weighted mean patch size is also known as correlation length and indicates the distance that one might expect to traverse the map while staying in a particular patch, from a random starting point and moving in a random direction (Keitt et al., 1997). The boundaries between patches (or edges) represent another fundamental spatial attribute of a patch mosaic. The most common measures of patch shape complexity are based on the perimeter-to-area ratio. Aggregation indices measure the degree of clumping of patch types and are also referred to as metrics of landscape texture.

For each wildfire area selected, the following five landscape metrics were compared for high NDVI values ( $>$ 0.5 ) within the HBS class: Area-weighted mean patch area (AREA_AM), Coefficient of variation in patch area (AREA_CV), Largest patch index (LPI), Landscape shape index (LSI), and Clumpiness index (CLUMPY). AREA_AM provides an absolute measure of patch structure, whereas LPI quantifies the percentage of total landscape area comprised by the largest patch; as such, is a relative measure of dominance. The LSI is a metric of the amount of edge present in a landscape and expresses the perimeter-to-area ratio for the class as a whole. It can be interpreted as a measure of the overall geometric complexity of the class in a given landscape. The higher the LSI, the higher the amount of edge area at the landscape scale. CLUMPY is a metric that ranges from -1 when the patch type is maximally disaggregated to +1 when the patch type is maximally clumped. It returns a value of zero for a random distribution.

\section{Results}

The spatial patterns of all HBS class areas with high NDVI was shown in Figure 2 for visual comparisons of each of the fires selected for analysis. The proportion of HBS class area with high NDVI values $(>0.5)$ in 2013 was greater than $69 \%$ for the two fires that occurred in the late 1990s, Ackerson and Bucks (Table 1). The proportion of HBS class area with high NDVI decreased to less than $40 \%$ in the McNally and American River fires of the mid-2000s, and to less than 2\% for the Chips fire of 2012. For the 1948 Rancheria Mountain fire area, the total area with high NDVI (>0.5) in 2013, but not the proportion of HBS class area (due to lack of a RdNBR layer for 1949), could be approximated based on current cover of woody vegetation types.

\subsection{Variability in Patch Area of High NDVI}

The AREA_AM metric estimated for high NDVI ( $>0.5)$ patches within the 1948 Rancheria Mountain fire area increased steadily from 85 ha in 1985 to over 215 ha by 2013, along with a modest increase in the associated the AREA_CV values over the past $25+$ years (Table 2). After more than 60 years of regrowth, the AREA_AM metric for the 1948 Rancheria Mountain fire area was estimated to be three times higher than any of the fires that occurred after 1995.

Table 2. Landscape metrics for high NDVI $(>0.5)$ patches determined form Landsat images within the HBS class of selected large fires in the Sierra-Nevada.

\begin{tabular}{cccccc}
\hline Fire Name & AREA_AM & AREA_CV & LPI & LSI & CLUMPY \\
Rancheria Mountain 1985 & 85.2 & 499 & 24.7 & 16.6 & 0.82 \\
Rancheria Mountain 2005 & 167.8 & 627 & 29.1 & 15.9 & 0.84 \\
Rancheria Mountain 2013 & 216.0 & 655 & 36.6 & 17.3 & 0.84 \\
Ackerson 2005 & 51.2 & 628 & 5.8 & 47.2 & 0.75 \\
Ackerson 2013 & 71.6 & 679 & 4.9 & 46.4 & 0.75 \\
Bucks 2005 & 51.6 & 609 & 9.0 & 32.9 & 0.75 \\
Bucks 2013 & 49.0 & 579 & 3.3 & 32.8 & 0.75 \\
McNally 2005 & 26.8 & 600 & 3.7 & 75.8 & 0.64 \\
McNally 2013 & 51.7 & 746 & 1.7 & 77.1 & 0.68 \\
American River 2013 & 38.4 & 817 & 4.5 & 41.5 & 0.60 \\
Chips 2013 & 1.6 & 251 & 0.0 & 22.2 & 0.38 \\
\hline
\end{tabular}


Rancheria Mountain 1948

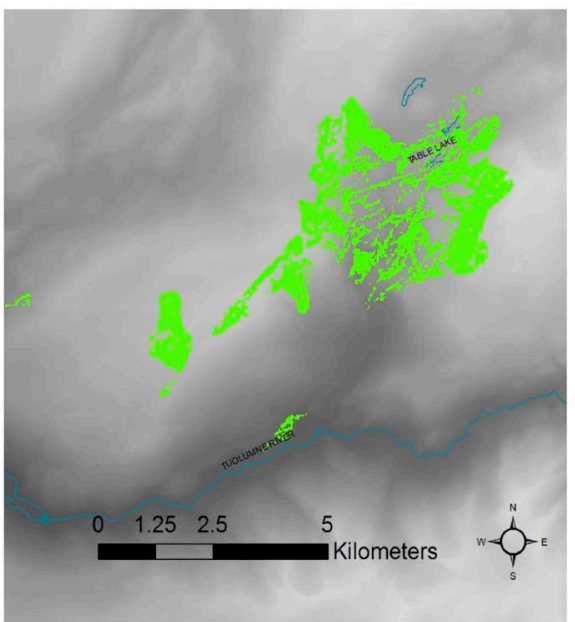

Ackerson 1996

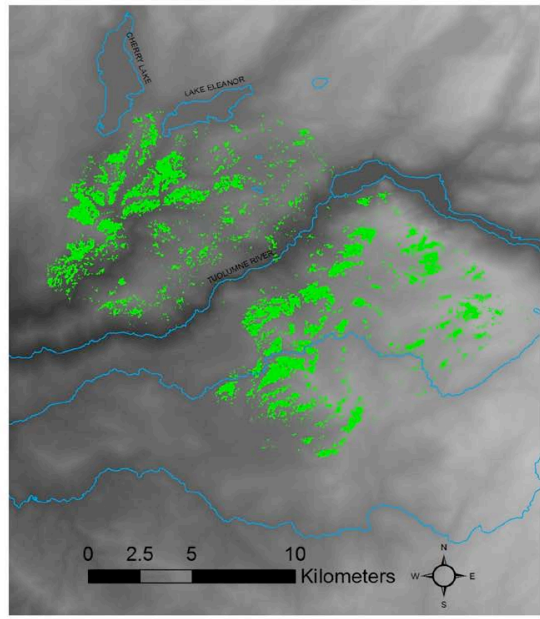

(a)

Bucks 1999

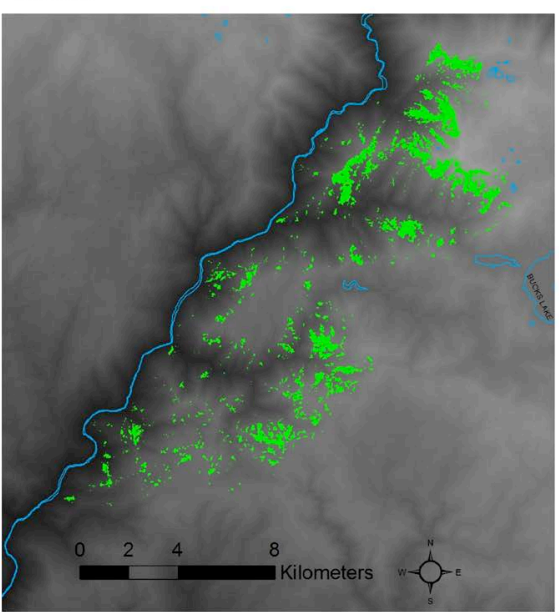

McNally 2002

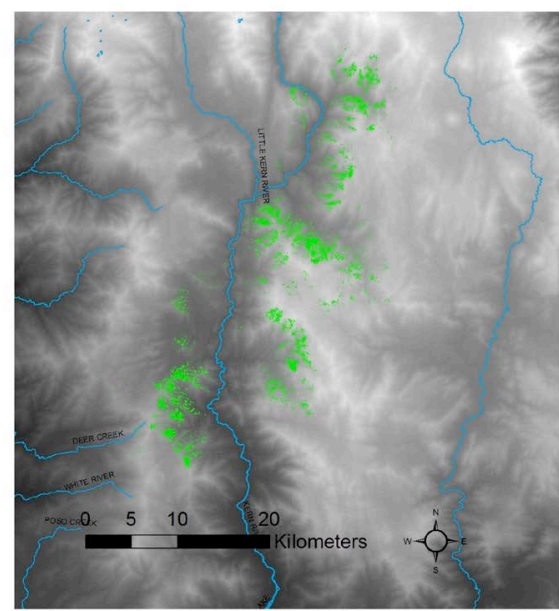

(b)

American River 2008

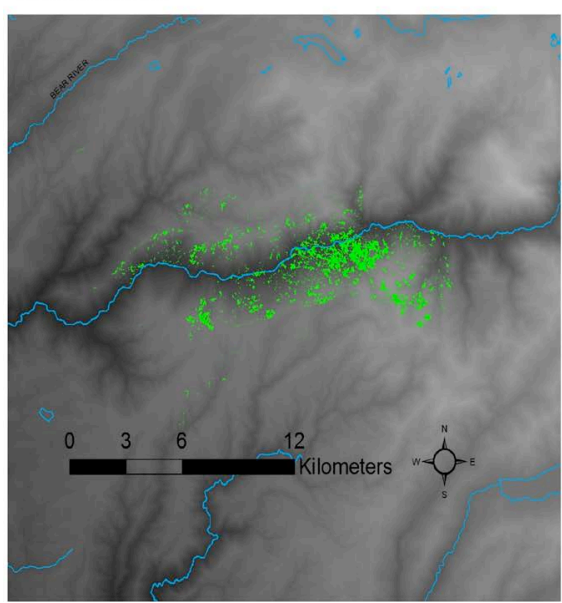

Chips 2012

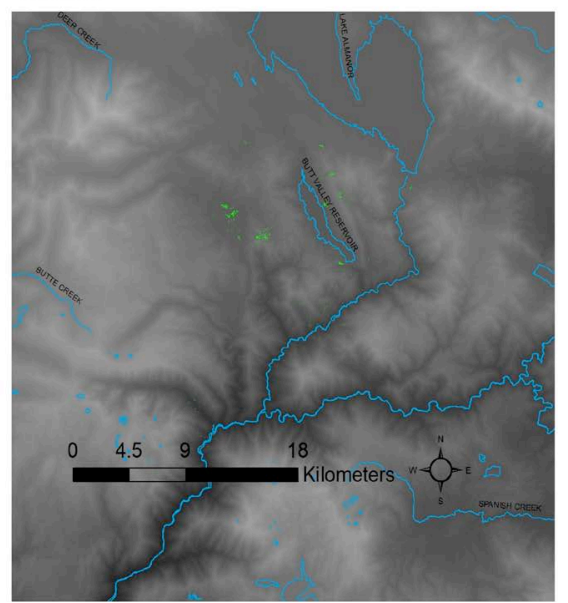

(c)

Figure 2. High NDVI ( $>0.5$ ) patches from July-August 2013 Landsat images (green 30-m pixels) within the HBS class estimated for wildfires listed in Table 1. Base maps are shaded elevation with major river channels and water bodies in blue lines. 
By comparison, the AREA_AM metric decreased from just over 70 ha in the Ackerson fire of 1996 to less than 2 ha in the Chips fire of 2102, with the fires between following the overall decreasing trend in patch area with time to the present year (Table 2). For fires that occurred after 1995, the AREA_CV values showed no clear trend with time since fire, with the exception of a much lower AREA_CV value for the Chips fire of 2012 than for any of the previous fires.

\subsection{Variability in Patch Dominance of High NDVI}

For fires that occurred after 1995, the LPI metric was highest for the Ackerson and the American River fires, and was lowest for the McNally and Chips fires. However, the percentage of total landscape area comprised by the largest patch of high NDVI was relatively small in all five fires, as would be expected in a large burned area with a complex mosaic of different burn severity classes fragmenting one another on the landscape (Figure 2).

The LPI metric for high NDVI patches within the 1948 Rancheria Mountain fire area increased steadily from 1985 to 2013, and was estimated at seven times higher after 60+ years of regrowth (by 2013) than for any of the fire areas that were burned after 1995. These findings indicated that the proportion of total burned landscape area comprised by the largest patch of high NDVI values adds fractional area at a rate of approximately $0.5 \%$ to $0.6 \%$ per year across the Sierra Nevada study region.

\subsection{Variability in Patch Complexity of High NDVI}

The LSI metric was highest for the McNally fire, but then decreased by around 50\% for the other fires that occurred after 1995, following a generally decreasing pattern of overall patch complexity with time to the present year. The HBS areas and high NDVI patches within the McNally fire were located at a relatively high elevation (mostly above $1900 \mathrm{~m}$ and as high as $2715 \mathrm{~m}$ ), and in more steeply varying terrain than the high NDVI patches of the other fires, which were nearly all located below $2000 \mathrm{~m}$ elevation (Figure 2). This resulted in a higher perimeter-to-area ratio for the high NDVI patches as a whole McNally fire, which also had twice as much total HBS area as any of the other four fires that occurred after 1995.

The LSI metric was lowest for the 1948 Rancheria Mountain fire area, which showed a greatly reduced perimeter-to-area ratio of high NDVI areas and low overall patch complexity after more than six decades of regrowth. The LSI metric was also relatively low for the 2012 Chips fire, which had very few high NDVI patches in 2103 and therefore low initial burned area complexity one year after fire, compared to any of the previous fires analyzed.

\subsection{Variability in Patch Aggregation of High NDVI}

The CLUMPY metric showed the same general trend with time since fire as the AREA_AM metric, but with some additional information on aggregation patterns. First, the range of values of CLUMPY (0.84 - 0.38) for all fires indicated that the high NDVI areas in all cases were more aggregated than expected for a spatially random distribution. Second, the two fires of the 1990s, Ackerson and Bucks, were equally aggregated, whereas the aggregation level dropped steadily for the three more recent fires that occurred after 1995.

\section{Discussion}

In the Sierra-Nevada, HBS areas are those most likely to have experienced stand-replacing wildfire (Miller et al., 2009), and would have started to recover vegetation biomass from nearly bare and sometimes charred ground. In subsequent years, the detection of NDVI values greater than 0.5 would be indicative of recovery of dense canopy cover in conifer forest and shrubland cover after stand-replacing fires the central Sierra Nevada (van Wagtendonk \& Root, 2003). Results from the present analysis of Landsat NDVI since 1996 showed that dense cover types (NDVI $>0.5$ ) have recovered on a trajectory from less than $2 \%$ coverage of HBS areas in the year after standreplacing wildfire to greater than $65 \%$ dense canopy cover of HBS areas in just over 15 years after wildfire. Based on comparison to a large burned area in central Yosemite National Park following six decades of woody cover (shrub and forest types) regrowth, the average patch area of high NDVI may continue to increase by several fold (to over $200 \mathrm{ha}$ ) over next 50 years, with the patch perimeter-to-area ratio declining accordingly, for the fires that occurred since the mid 1990s. 
Analysis of landscape metrics showed that average area-weighted patch size of recovered dense canopy cover types reached 70 ha by 15 years since wildfire in the Sierra-Nevada. The percentage of total landscape area comprised by the largest patch of recovered dense canopy cover types was relatively small in all fires studied, presumably due to the complex mosaic of different burn severity classes, but increased rapidly with time since fire. Patch complexity of recovered dense canopy cover types was not readily associated with time since fire since the mid 1990s, but was consistently high in all fires studied and had a tendency to increase with the elevation of HBS areas. Patches with recovery of dense canopy cover levels in the fires studied were more aggregated than expected for a spatially random distribution, and the spatial aggregation level increased steadily with time since fire.

Comparison of the post-fire forest structure in the Sierra-Nevada to other forests of the western United States can be put into the context starting with Yellowstone National Park (YNP), where Tinker et al. (2003) reported that average forest patch size was 354 ha in YNP prior to the 1988 fires, and was reduced to 253 ha after large wildfire of 1988. Patch size standard deviation decreased nearly two-fold after 1988 relative to the previous 280 years, suggesting that patches across YNP had become more similar in size after extensive wildfires. Edge density increased from 9.8 to $14.2 \mathrm{~m} \cdot \mathrm{ha}^{-1}$ prior to 1988 to over $17 \mathrm{~m} \cdot \mathrm{ha}^{-1}$ afterwards.

Kane et al. (2013) reported that, as fire severity increased in areas sampled within Yosemite National Park between 1984 and 2010, total area of forest canopy decreased while the number of clumps increased, indicating progressive fragmentation of remaining canopy into smaller clumps. Aggregation of patches within individual canopy strata showed only modest changes as fire severity increased. Low- to moderate-severity fires most closely replicated the clump-opening patterns that were historically common in central Sierra forests under a relatively frequent wild land fire regime.

The plant species composition of regrowing vegetation types cannot be inferred from NDVI alone. On this subject, previous studies of Sierra Nevada forest succession (Conard \& Radosevich 1982; Russell et al. 1998; Nagel \& Taylor, 2005) have indicated that regrowth trajectories of conifer forests can be highly uncertain. Specific to the present study, Syfert et al. (2006) reported that shrubs (Ceanothus spp. and Arctostaphylos spp.) dominated post-burn plots surveyed in the Ackerson fire in 2005, with regenerating pines covering only $3 \%$ of the sample plot areas. Collins \& Roller (2013) reported that over one-half of the sampled patches where stand-replacing burns had occurred in the Bucks fire (and nearby burned areas) had no tree regeneration and almost three-quarters of the patches had no pine regeneration eleven years post-fire. Excluding patches that had post-fire management activities (such as salvage harvesting and replanting), there was no pine regeneration in over $90 \%$ of the sampled patches.

\section{Conclusion and Implications}

Analysis of landscape metrics from Landsat NDVI showed that the percentage of total HBS area comprised by the largest patch of recovered woody cover was relatively small in all fires that occurred since 1995, but increased rapidly with time since fire. Patch complexity of recovered woody cover decreased notably after more than 50 years of woody cover regrowth. Despite the fact that satellite image analysis now offers effective regional data sets for measuring spatial patterns of vegetation recovery from disturbance in mountain landscapes, relatively little is known about the consequences of woody recovery patterns for future fire return intervals and intensities, as well as for long-term successional trajectories and associated wildlife population changes in the Sierra-Nevada. Human activities are impacting fire season lengths and return intervals by frequent accidental ignitions. Suppression efforts can inhibit the spread of wildfires while they are still small, but uncontrolled events can grow to sizes much larger than will occur naturally because of the historical increases in fuel loading. The satellite remote sensing approach used in this study based on yearly NDVI mapping can help monitor recovery rates of dense canopy types in all woody cover ecosystems of the region.

\section{References}

Aha, N., Boorman, M., Leidman, S., \& Perry, S. (2014). The Effect of Sediment Deposition on Sierra Riverine Ecosystems Following High-Intensity Fires (13 p). Davis, CA: Center for Watershed Sciences, University of California. https://watershed.ucdavis.edu/education/

Avery, T. E., \& Berlin, G. L. (1992). Fundamentals of Remote Sensing and Airphoto Interpretation (472 p). Upper Saddle River, NJ: Prentice Hall. 
Board of Review Report (1948). Rancheria Mountain Fire, Yosemite National Park, 9-21 September 1948, 1-3.

Casady, G. M., \& Marsh, S. E. (2010). Broad-Scale Environmental Conditions Responsible for Post-Fire Vegetation Dynamics. Remote Sensing, 2, 2643-2664. http://dx.doi.org/10.3390/rs2122643

Chander, G., Markham, B., \& Helder, D. (2009). Summary of Current Radiometric Calibration Coefficients for Landsat MSS, TM, ETM+, and EO-1 ALI Sensors, Remote Sensing of the Environment, 113, 893-903. http://dx.doi.org/10.1016/j.rse.2009.01.007

Collins, B. M., \& Roller, G. B. (2013). Early Forest Dynamics in Stand-Replacing Fire Patches in the Northern Sierra Nevada, California, USA. Landscape Ecol., 28, 1801-1813.

Collins, J. B., \& Woodcock, C. E. (1996). An Assessment of Several Linear Change Detection Techniques for Mapping Forest Mortality Using Multitemporal Landsat TM Data. Remote Sensing of Environment, 56, 66-77. http://dx.doi.org/10.1016/0034-4257(95)00233-2

Conard, S. G., \& Radosevich, S. R. (1982). Post-Fire Succession in White Fir (Abies Concolor) Vegetation of the Northern Sierra Nevada. Madrono, 29, 42-56.

Cuevas-Gonzalez, M., Gerard, F., Balzter, H., \& Riano, D. (2009). Analysing Forest Recovery after Wildfire Disturbance in Boreal Siberia Using Remotely Sensed Vegetation Indices. Global Change Biology, 15, 561-577. doi: $10.1111 / \mathrm{j} .1365-2486.2008 .01784$.

Eidenshenk, J., Schwind, B., Brewer, K., Zhu, Z., Quayle, B., \& Howard, S. (2007). A Project for Monitoring Trends in Burn Severity. Fire Ecology, 3, 3-21. http://dx.doi.org/10.4996/fireecology.0301003

Epting, J., \& Verbyla, D. L. (2005). Landscape Level Interactions of Pre-Fire Vegetation, Burn Severity, and Post-Fire Vegetation over a 16-Year Period in Interior Alaska. Canadian Journal of Forest Research, 35, 1367-1377. http://dx.doi.org/10.1139/x05-060

Fischer, L., Rosenberg, M., Mahon, L., Liu, Z., Maurizi, B., Longmire, P., \& Shupe, S. (2004). Monitoring Land Cover Changes in California, a USFS and CDF Cooperative Program, Northern Sierra Project Area-Cycle II. Sacramento, CA: State of California, Resources Agency, Department of Forestry and Fire Protection.

Fontaine, J. B., \& Kennedy, P. L. (2012). Meta-Analysis of Avian and Small-Mammal Response to Fire Severity and Fire Surrogate Treatments in U.S. Fire-Prone Forests. Ecological Applications, 22, 1547-1561. http://dx.doi.org/10.1890/12-0009.1

Franks, S., Masek, J. G., \& Turner, M. G. (2013). Monitoring Forest Regrowth Following Large Scale Fire Using Satellite Data-A Case Study of Yellowstone National Park, USA. European Journal of Remote Sensing, 46, 561-569. http://dx.doi.org/10.5721/eujrs20134632

Goforth, B. R., \& Minnich, R.A. (2008). Densification, Stand-Replacement Wildfire, and Extirpation of Mixed Conifer Forest in Cuyamaca Rancho State Park, Southern California. Forest Ecology and Management, 256, 36-45. http://dx.doi.org/10.1016/j.foreco.2008.03.032

Kane, V. R., North, M. P., Lutz, J. A., Churchill, D. J., Roberts, S. L., Smith, D. F., McGaughey, R. J., Kane, J. T., \& Brooks, M. L. (2013). Assessing Fire Effects on Forest Spatial Structure Using a Fusion of Landsat and Airborne LiDAR Data in Yosemite National Park. Remote Sensing of Environment, 151, 89-101. http://dx.doi.org/10.1016/j.rse.2013.07.041.

Keitt, T. H., Urban, D. L., \& Milne, B. T. (1997). Detecting Critical Scales in Fragmented Landscapes. Conservation Ecology, 1, 4.

Key, C. H., \& Benson, N. C. (2006). Landscape Assessment: Ground Measure of Severity, the Composite Burn Index; and Remote Sensing of Severity, the Normalized Burn Ratio. In D. C. Lutes, R. E. Keane, J. F. Caratti, C. H. Key, N. C. Benson, S. Sutherland, \& L. J. Gangi (Eds.), FIREMON: Fire Effects Monitoring and Inventory System. Ogden, UT: USDA Forest Service, Rocky Mountain Research Station, Gen. Tech. Rep.

Lentile, L., Holden, A., Smith, A., Falkowski, M., Hudak, A., Morgan, P. et al. (2006). Remote Sensing Techniques to Assess Active Fire Characteristics and Post-Fire Effects. International Journal of Wildland Fire, 15, 319-345. http://dx.doi.org/10.1071/WF05097

Li, S., \& Potter, C. (2012). Vegetation Regrowth Trends in Post Forest Fire Ecosystems across North America from 2000 to 2010. Natural Science, 4, 755-770. http://dx.doi.org/10.4236/ns.2012.410100

Lutz, J. A., van Wagtendonk, J. W., \& Franklin, J. F. (2009) Twentieth-Century Decline of Large-Diameter Trees in Yosemite National Park, California, USA. Forest Ecology and Management, 257, 2296-2307. http://dx.doi.org/10.1016/j.foreco.2009.03.009

McGarigal, K., Cushman, S. A., Neel, M. C., \& Ene, E. (2002). FRAGSTATS: Spatial Pattern Analysis Program for Categorical Maps. Amherst: University of Massachusetts. www.umass.edu/landeco/research/fragstats/fragstats.html 
Miller, J. D., \& Safford, H. (2012). Trends in Wildfire Severity: 1984 to 2010 in the Sierra Nevada, Modoc Plateau, and Southern Cascades, California, USA. Fire Ecology, 8, 41-57. http://dx.doi.org/10.4996/fireecology.0803041

Miller, J. D., \& Yool, S. R. (2002). Mapping Forest Post-Fire Canopy consumption in Several Overstory Types Using Multi-Temporal Landsat TM and ETM Data. Remote Sensing of Environment, 82, 481-496. http://dx.doi.org/10.1016/S0034-4257(02)00071-8

Miller, J. D., Knapp, E. E., Key, C. H., Skinner, C. N., Isbell, C. J., Creasy, R. M., \& Sherlock, J. W. (2009). Calibration and Validation of the Relative Differenced Normalized Burn Ratio (RdNBR) to Three Measures of Fire Severity in the Sierra Nevada and Klamath Mountains, California, USA. Remote Sensing of Environment, 113, 645-656.

http://dx.doi.org/10.1016/j.rse.2008.11.009

Nagel, T.A., \& Taylor, A. H. (2005). Fire and Persistence of Montane Chaparral in Mixed Conifer Forest Landscapes in the Northern Sierra Nevada, Lake Tahoe Basin, California, USA. Torrey Botanical Society, 132, 442-457. http://dx.doi.org/10.3159/1095-5674(2005)132[442:FAPOMC]2.0.CO;2

National Park Service (NPS) (1949). Fire Control Plan. Yosemite National Park Archives.

National Park Service (NPS) (2009). Yosemite National Park Annual Fire Management Plan (pp. 74). Yosemite National Park, CA: Department of the Interior.

Potter, C. S. (2014). Ten Years of Forest Cover Change in the Sierra Nevada Detected Using Landsat Satellite Image Analysis. International Journal of Remote Sensing, 35, 7136-7153. http://dx.doi.org/10.1080/01431161.2014.968687

Potter, C., Li, S., Huang, S., \& Crabtree, R. L. (2012). Analysis of Sapling Density Regeneration in Yellowstone National Park with Hyperspectral Remote Sensing Data. Remote Sensing of Environment, 121, 61-68. http://dx.doi.org/10.1016/j.rse.2012.01.019

Roberts, S. L., Kelt, D. A., van Wagtendonk, J. W., Miles, A. K., \& Meyer, M. D. (2015) Effects of Fire on Small Mammal Communities in Frequent-Fire Forests in California. Journal of Mammalogy, 96, 107-119. http://dx.doi.org/10.1093/jmammal/gyu011

Rogan, J., \& Franklin, J. (2001). Mapping Wildfire Burn Severity in Southern California Forests and Shrublands Using Enhanced Thematic Mapper Imagery. Geocarto International, 16, 89-99. http://dx.doi.org/10.1080/10106040108542218

Rogan, J., Miller, J., Stow, D. A., Franklin, J., Levien, L., \& Fischer, C. (2003). Land-Cover Change Monitoring with Classification Trees Using Landsat TM and Ancillary Data. Photogrammetric Engineering and Remote Sensing, 69, 793-804. http://dx.doi.org/10.14358/PERS.69.7.793

Rundel, P. W., Parsons, D. J., \& Gordon, D. T. (1977). Montane and Subalpine Vegetation of the Sierra Nevada and Cascade Ranges. In M. G. Barbour, \& J. Major (Eds.), Terrestrial Vegetation of California (pp. 559-599). New York: Wiley.

Russell, W. H., McBride, J. R., \& Rowntree, R., (1998). Revegetation after Four Stand-Replacing Fires in the Lake Tahoe Basin. Madrono, 45, 40-46.

Safford, H. D., van de Water, K., \& Schmidt, D. (2011). California Fire Return Interval Departure (FRID) Map, 2010 Version. USDA Forest Service, Pacific Southwest Region and the Nature Conservancy-California. http://www.fs.fed.us/r5/rsl/clearinghouse/r5gis/frid/

Syfert, M., Rudy, J., Anderson, L., Cleve, C., Jenkins, J., Skiles, J. W., \& Schmidt, C. (2006) Post-Fire Regeneration Assessment in Yosemite National Park. ASPRS Annual Conference Reno (p. 9), Nevada, 1-5 May 2006.

Tinker, D. B., Romme, W. H., \& Despain, D. G. (2003) Historic Range of Variability in Landscape Structure in Subalpine Forests of the Greater Yellowstone Area, USA. Landscape Ecology, 18, 427-439. http://dx.doi.org/10.1023/A:1026156900092

Trujillo, E., Molotch, N. P., Goulden, M. L., Kelly, A. E., \& Bales, R. C. (2012). Elevation-Dependent Influence of Snow Accumulation. Nature Geoscience, 5, 705-709.

USDA Natural Resources Conservation Service (2006). Land Resource Regions and Major Land Resource Areas (MRLAs) of the United States, the Caribbean, and the Pacific Basin. U.S. Department of Agriculture Handbook 296.

Van de Water, K., \& Safford, H. D. (2011). A Summary of Fire Frequency Estimates for California Vegetation before Euro-American Settlement. Fire Ecology, 7, 26-58. http://dx.doi.org/10.4996/fireecology.0703026

van Mantgem, P. J., \& Schwilk, D. W. (2009). Negligible Influence of Spatial Autocorrelation in the Assessment of Fire Effects in a Mixed Conifer forest. Fire Ecology, 5, 116-125. http://dx.doi.org/10.4996/fireecology.0502116

van Wagtendonk, J. W., \& Lutz, J. A. (2007). Fire Regime Attributes of Wildland Fires in Yosemite National Park. Fire Ecology, 3, 34-52. http://dx.doi.org/10.4996/fireecology.0302034

van Wagtendonk, J. W., \& Root, R. R. (2003). The Use of Multi-Temporal Landsat Normalized Difference Vegetation Index (NDVI) Data for Mapping Fuel Models in Yosemite National Park, USA. International Journal of Remote Sensing, 24, 1639-1651. http://dx.doi.org/10.1080/01431160210144679 